\title{
最近の研究から
}

\section{アーク放電法で作製した多層および 単層カーボンナノチューブ}

\section{名城大学理工学部 安藤義則}

\author{
Yoshinori ANDO: Multi-Walled and Singlewall Carbon Nanotubes Produced by \\ Arc Discharge Method
}

Multi-walled carbon nanotubes (MWNTs) and singlewall carbon nanotubes (SWNTs) are produced by dc arc discharge evaporation. In the case of MWNTs, hydrogen arc discharge was effective to make highly crystallised ones and with the thinnest inner tubes. In Raman spectra of MWNTs, radial breathing modes corresponding to the thinnest inner tube were observed. Mass production of SWNTs by arc discharge evaporation was carried out by arc plasma jet method. Hydrogen gas or addition of $1 \% \mathrm{H}_{2} \mathrm{~S}$ gas also was effective to prepare SWNTs by arc discharge.

\section{1.はじめに}

カーボンナノチューブが発見りされて今年でちょうど 10 年になる. 当時, NECの飯島 (現名城大学・理工学部 教授) が筆者らの研究室の机上に放置されていた蒸発済 みのカーボン電極を見て，これを高分解能電子顕微鏡 (HR-TEM) で観察してもよいかと尋ねられた。もちろ ん, よいですよと返事したのが, 後にセレンディピティ 一と言われるカーボンナノチューブ発見のきっかけとな った。とは言っても，飯島はそれまでいろいろのカーボ ンの HR-TEM 観察を行ってきていた. 特に1980年にはカ 一ボン膜の中に玉ねぎ構造をもつものがあり，2）その一 番内側の球の直径は, 1985 年にクロトーら 31 によって発 見された $\mathrm{C}_{60}$ のそれとほぼ同じであることに後になって 気づいた.4)しかし，皆がやろうとしているフラーレンと 同じことを後追いするのではなく，異なったアプローチ をしたいという彼の強い意志がセレンディピティーを生 んだとも言える。

最初に発見されたカーボンナノチューブは,グラッフ エンシートが筒状に巻いたものが何重にも重なった多層 カーボンナノチューブ (multi-walled carbon nanotubes: MWNTs) であった。後に発見されたグラッフェンシート 1 枚だけが筒状に巻いた単層カーボンナノチューブ (singlewall carbon nanotubes: SWNTs) 5),6) とは区別される。そ の作製法も両者でかなり異なっている.

MWNTs の作製法としては，最初に発見された試料が 黒鉛の直流アーク放電蒸発で作製されたものであり，1)他 に化学気相成長法 (Chemical Vapor Deposition; CVD) 7) あるいは炭化ケイ素単結晶の表面を高温で熱酸化させる

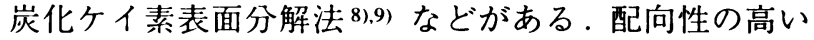
MWNTs を高収率で得るという目的では, 後二者为優れ ているが, 結晶性の高いMWNTs を得るという目的では アーク法の方が優れていることが知られている.

一方, SWNTs も最初はアーク法で作製された.5),6) た だし, 蒸発原料としての炭素棒に触媒としての適当な金 属の存在が不可欠であることが, MWNTs とは大きく異 なる点である．また，同じ作製容器を用いても，できる 場所がMWNTs と SWNTs とではまったく異なっている のも特徵的である.すなわち, MWNTs の場合には陰極堆 積物の中にしか作製されないが, SWNTsの場合には蒸 発装置全体にわたって，くもの巣状の煤として作製され る.また, SWNTs を高収率で作製するためには, 金属触 媒入りの黑鉛電極のレーザー蒸発も有効であることが知 られている.10) しかし, レーザー法の場合, 収量は数十 $\mathrm{mg} / \mathrm{h}$ 程度とそれほど多くないのが難点である．

以前に結晶学会誌には, “最近の研究から”の欄に比較 的初期の段階におけるカーボンナノチューブの作製につ いて MWNTsを主として記述した.11)ここでは, 作製法を アーク放電法に限定して, 我々の研究室で得られた結果 を主にして, MWNTs とSWNTs の両方について, その作 製法と作製されたカーボンナノチューブの特徴を述べる. 特に, 我々は高結晶性の MWNTs と SWNTs の量産化をめ ざして成果を得つつある，それを用いた各種の応用が期 待されるところである.

\section{2. アーク法によるMWNTs の作製}

\subsection{MWNTs の作製装置}

アーク放電でMWNTs を作製する装置の模式図を図 1 
に示す。この装置は，もともとはガス蒸発法12) で炭化ケ イ素の超微粉13) を大量に作製するために開発された装置 で, 250 A までのアーク電流が流せる. 容器の中を油拡 散ポンプで $1.0 \times 10^{-5}$ Torr の高真空まで排気した後, 適 当な雰囲気ガスを所定の圧力まで導入する．その中で2 本の黒鉛棒を電極（下側を陽極，上側を㓌極）とする直流 アーク放電を生じさせると, 陽極が蒸発して炭素の煤が 発生する，その際，雲囲気ガスを例えばへリウムのよう な不活性ガスにすると, 発生した炭素煤の中に $\mathrm{C}_{60}$ に代表 されるフラーレンが含まれていることがクレッチマーら によって 1990 年に見出された.14) 我々も1991 年の初頭か らこの装置を用いて， $\mathrm{C}_{60}$ の作製を始めた。そのとき，蒸 発した炭素煤の一部は直上の㓌極に堆積する。その堆積 物が机上に置かれているのを見て，その中に宝物がある と直感したのが飯島のカーボンナノチューブの発見につ ながった.1) それから 10 年, 我々のところではアーク法 にこだわったカーボンナノチューブ作製を続けている．

なお,図1の2本の電極は, 上下を逆にして設置するこ とも可能であるが，対流の関係もあって陰極堆積物を多 く得たいMWNTs 作製の場合は，図1のように下を陽極 にして上の除極に付着させるようにした方が効率的であ る.また，電極を水平に対置させることも可能であり， その場合も対流の効果が少し異なる程度である．逆に後 述寸るSWNTs 作製の場合は，陰極堆積物ができないほう が望ましく，そのためには陽極を上にした方が良い結果 が得られる。

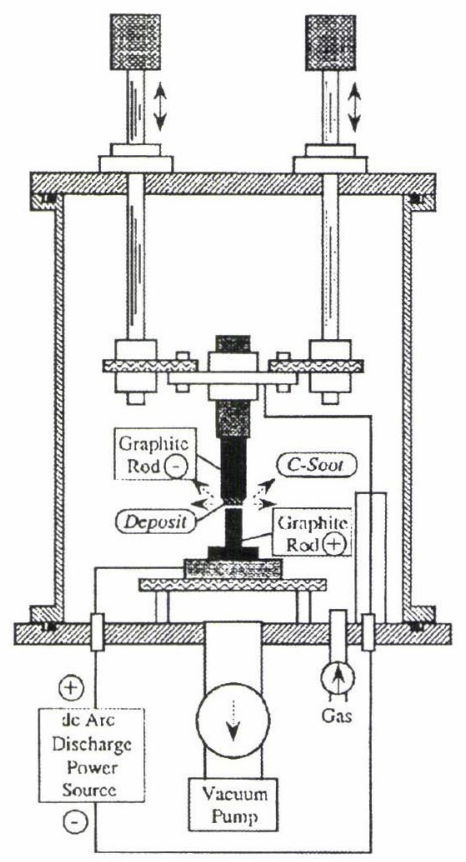

図1 カーボンナノチューブ作製用アーク蒸発装置.(Arc evaporation apparatus for carbon nanotube production.)

\section{2 雾囲気ガスの効果}

アーク蒸発を行うときの雲囲気ガスとしては,ヘリウ ムやアルゴンなどの不活性ガスのみならず, 炭化ケイ素 超微粉のストイキオメトリーを上げるのに有効だったメ タンガス13) も用いてみた。図2および図3にヘリウムお よびメタンガス中で作製した㓌極堆積物の表面中央部 ${ }^{15)}$ の走査型電子顕微鏡 $(\mathrm{SEM})$ 写真を示す. そこにファイバ 一状のものとして確認できるのがMWNTsである。この 結果から雲囲気ガスの圧力やアーク電流によっても著し く異なるが，ヘリウムガスよりもメタンガスの方が MWNTs を作るのに向いているようにも見られる.16)これ は， $\mathrm{C}_{60}$ の場合には水素原子を含むガス雲囲気中では作製 されないという常識とは明らかに異なる結果である。我々 はその違いを実験的に解明するために，メタンガス中で アーク蒸発を行った後, 雾囲気ガスを質量分析してみた その結果, メタンガスが熱分解して水素ガスとアセチレ ンガスになっていることが確認された.17) すなわち，

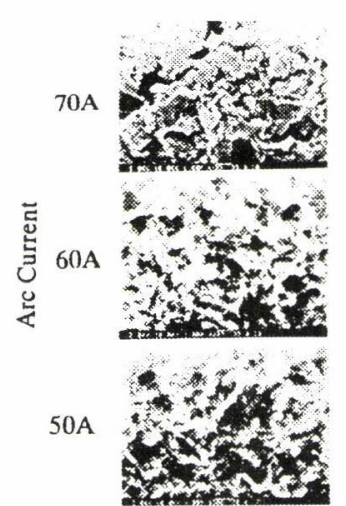

50 Torr

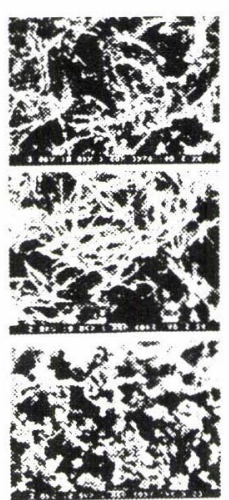

100 Torr He gas pressure

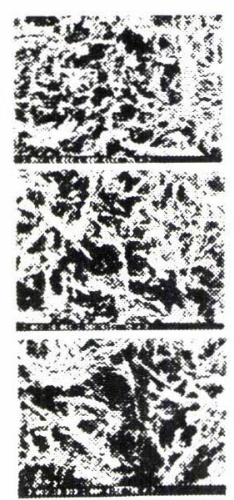

200 Torr
図2ヘリウムガス中で作製したMWNTs の SEM 写真 (SEM micrographs of MWNTs produced in He gas.)

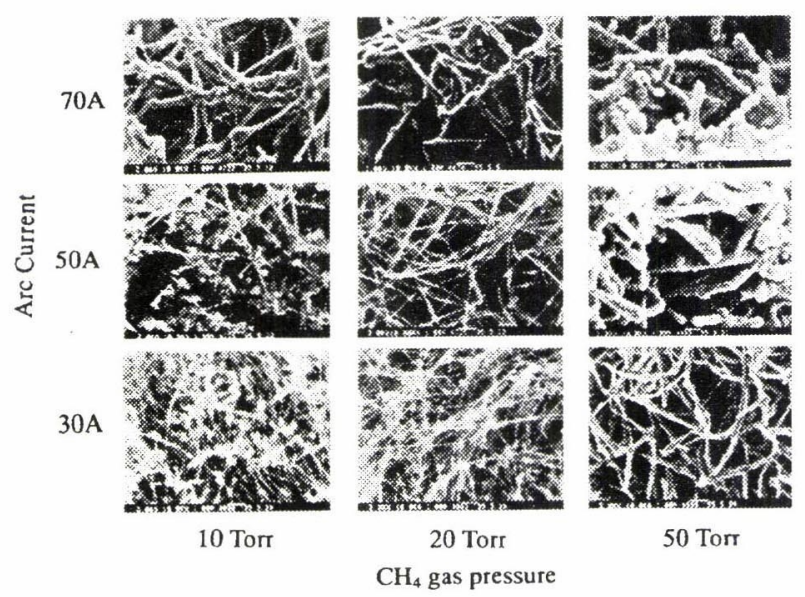

図3メタンガス中で作製した MWNTs の SEM 写真. (SEM micrographs of MWNTs produced in $\mathrm{CH}_{4}$ gas.) 
$2 \mathrm{CH}_{4} \rightarrow 3 \mathrm{H}_{2}+\mathrm{C}_{2} \mathrm{H}_{2}$

の反応が生じていると考えられる。この反応におけるモ ル数が反応の前後で 2 倍になっているが，それに対応す る圧力変化が反応の前後で確認された.へリウムガス中 蒸発の場合は, 反応の前後の圧力上昇は約 1.05 倍で, そ れは雲囲気ガス温度の上昇に帰着される. それに対して, メタンガス中蒸発の場合は, 反応後圧力は確実に 2 倍に 上昇していた。したがって, 純粋な水素ガスあるいはア セチレンガスの中で, 同様のアーク蒸発を行ったらどう なるかを知る意味がでてきた．

\section{3 水素ガス中アーク放電による MWNTs の作製}

実際に雲囲気ガスの種類を変えてアーク蒸発を行ってみ たところ，アセチレンガス中ではメタンガスの場合とほと んど同じ結果が得られたが, 純粋な水素ガス中では図 4 に そのSEM写真を示すようにメタンガスの場合に比して， さらに細くて長いMWNTsが得られた。もう1つ特徴的 なことは, 共存しているナノ粒子が大変少ないことであ る。このように特徴的な MWNTs が, 水素ガス圧力 60 Torr の雲囲気中で $6 \mathrm{~mm} \phi$ の黑鉛電極に直流アーク電流 $50 \mathrm{~A}$ を 流して蒸発することによって作製できた.18) 陰極堆積物の 外款は白銀色をした炭素質の非常に硬いものであるという ことは，他の雲囲気ガスを用いた場合と同じである。 MWNTsが含まれているのはその内側の真っ黒な煤状に見 える部分であることも他の場合と同じである.

純粋な水素ガス中でアーク放電を行った場合，もう1 つ特徵的なことは, 白銀色の㓌極堆積物の外殼から更に 外側の広い範囲にうっすらと黒い堆積物がついているこ とである、その堆積物を SEM およびTEM で確認したと ころ, 花びら状のグラッフェンシートが集まったものが 一面にできていることがわかった.19) 我々はそれを,“炭 素のバラ”と呼ぶ。これは, 水素ガスアーク放電を行っ

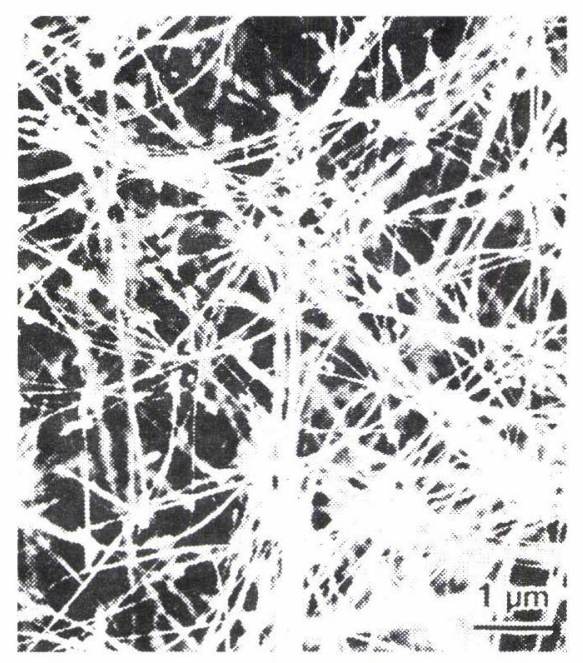

図4 水素ガス中で作製したMWNTsの SEM写真. (SEM micrograph of MWNTs produced in $\mathrm{H}_{2}$ gas.)
た場合,アークの炎の外側で, やや温度の低い部分にで きていることがわかった、メタンガスを用いた場合も，類 似のものが少しだけ得られていることが確認された。

一方，このように良質のMWNTsが作製される時間は 最初のアーク放電のスタートから安定した放電が継続す る約 1 分以内に限られるため，量を多く得ることができ ないのが難点である，それ以上放電を継続した場合，陰 極堆積物は時間とともに増大寸るが，そこに含まれるナ ノ粒子の量と大きさも増えるため, MWNTs としての質 の低下は避けられない，質の低下を無視して，堆積物の 厚みとして, $5 \mathrm{~mm}$ 以上のものを得ようとすると, 5 分以 上のアーク放電の継続が必要になる。しかも, 純粋な水 素ガス中でそれを行うときは, 時間の経過とともに堆積 物の中心部に硬い芯ができてしまうため，均質の堆積物 を作製するためには水素ガスの適当な流れを準備する必 要があることがわかった。

\section{4 水素ガス中アーク放電で作製した MWNTs の精製}

共存するナノ粒子が少ない場合は，それを除いて MWNTs を精製するのも容易である．図4 のSEM写真に 見られるような MWNTs を含む陰極堆積物を石英の試料 支持台の上に載せて, 空気中で赤外線照射して $500{ }^{\circ} \mathrm{C} に$ 30 分加熱するだけで，図 5 に見られるようにナノ粒子を 除去することができる.20),21) 30 分の赤外線加熱でこのよ

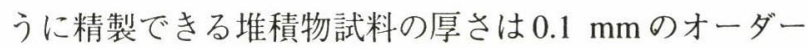
である. 通常 $6 \mathrm{~mm} \phi$ の黑鉛電極を 1 分間アーク蒸発させ て㓌極堆積物試料を作製するので, 精製物として得られ るサイズは $10 \mathrm{~mm}^{2} \times 0.1 \mathrm{~mm}=1 \mathrm{~mm}^{3}$ のオーダーであ

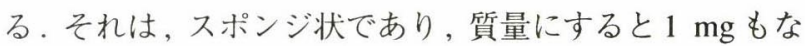
い程度であるが, ピンセットで取り扱うことは可能であ る、次節にこのように精製された試料を用いて得られた 種々の物理的特性を述べる。

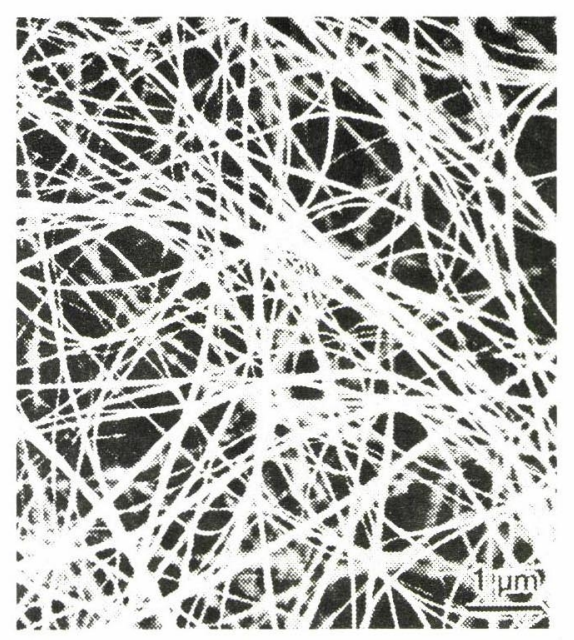

図5 水素ガス中で作製したMWNTs 赤外線照射で精 製したSEM写真. (SEM micrograph of purified MWNTs after produced by $\mathrm{H}_{2}$ arc.) 


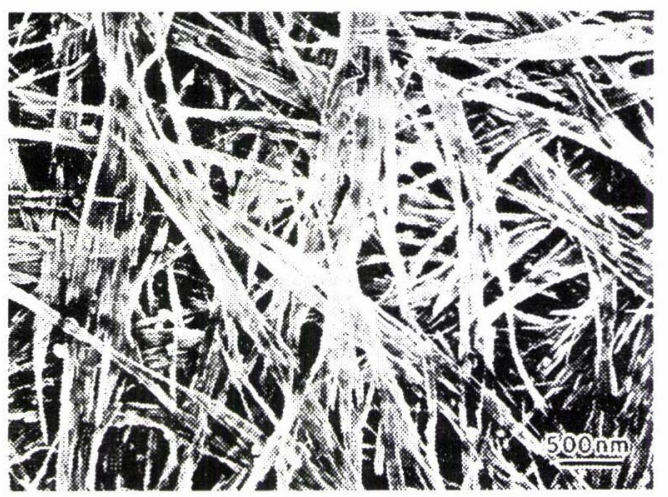

図6 精製したMWNTsのマット.(Mat of purified MWNTs.)

2.3 の後半に記述した $5 \mathrm{~mm}$ 以上の長い堆積物の場合 は，外側の殼を割ると中から MWNTsを含煤状の部分 を取り出すことができる。しかし，そこには多くのナノ 粒子とともに, 大きいものでは 1 ミクロン近い炭素の固 まりも含まれていることがSEM写真で確認できる.22)こ の場合は, 上述の赤外線照射で除去することは不可能で 本質的に異なった精製法の適用が必要になる。そこで， $20 \%$ 過酸化水素水で 45 時間加熱還流してアモルファス 炭素を除去し，そのあとナノ粒子などの不純物を除去す るため, 硫酸：硝酸=3：10混合溶液中で 24 時間加熱 還流した。その生成物を遠心分離して乾燥させると膜状 に配列したMWNTsが得られる。 そのSEM写真の一例 を図6に示す，そこではナノ粒子はほとんど除去され， MWNTsが束状に集合していることがわかる.しかし，精 製過程が複雑であるため, 最初の堆積物からすると最終 的に得られる精製物は数\%である。

\section{3. 水素ガス中アーク放電で作製した MWNTs の 物理的特性}

\subsection{HR-TEM 像}

水素ガス中アーク放電で作製した MWNTs の一本一本 をHR-TEM で観察すると，グラッフェンレイヤーが等間 隔に配列しており，結晶性が極めて高いことがわかる。 そ れに加えて特徴的なことは，中心の穴がへリウムガスの 中で作った MWNTsに比べてかなり細いことである.HRTEM 観察結果では, 中心の穴の直径分布は $1 \mathrm{~nm}$ が平均 で細いものではそれ以下であり， $\mathrm{C}_{60}$ や $\mathrm{C}_{36}$ の直径に対応 する7 § $5 \AA \AA$ のチューブも確認された.23) 最も細いも のでは図 7 に示すように中心の直径 $4 \AA$ のチューブも見 出されている.24)この太さはそれが閉じたときには $\mathrm{C}_{20}$ で キャップされることが予想され，理論的に予測されるチ ユーブとしても最小であることが予言されている。した がって, 水素ガス中アークで作製された MWNTsは, 通 常のSWNTs よりも細いチューブがその外側を何重にも 同心円状等間隔のグラッフェンシートで補強された (図7 の場合は 17 枚) 機械的強度も大変強いファイバーとして

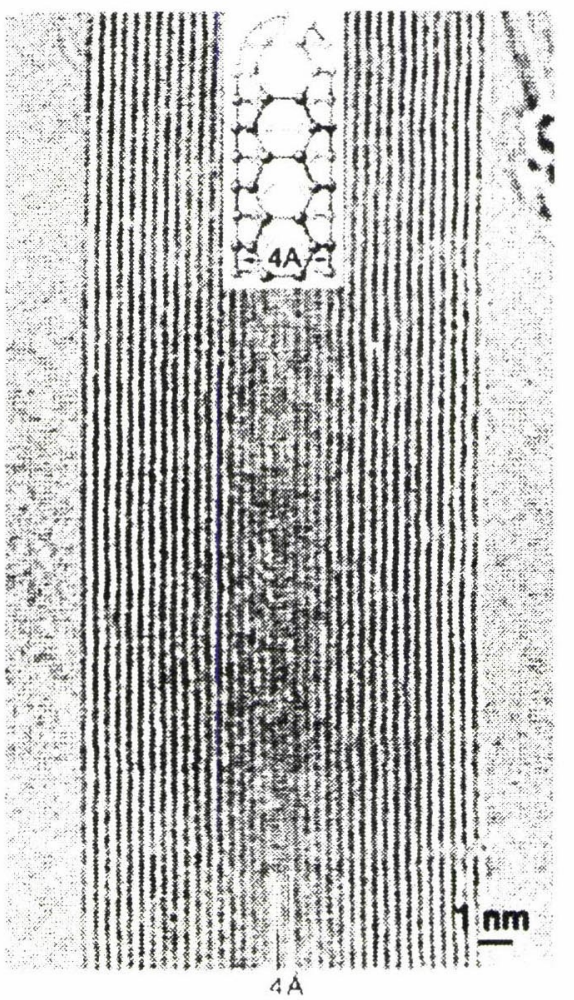

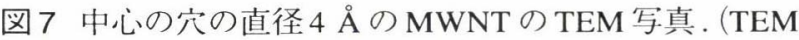
micrograph of MWNT with $4 \AA$ inner diameter.)

得られることがわかる

\subsection{MWNTs のラマンスペクトル}

図5のSEM写真に示すような精製した試料に励起波長 $514.5 \mathrm{~nm}$ のアルゴンレーザーを 1 ミクロン径に照射して マイクロラマン測定を行った結果, 得られたスペクトル を図8a およびbに示す. 図8a は低波数領域のスペクト ルで, 従来の MWNTsではピークは観測されていない領 域である。それに対して，図 8aでは何本もの動径方向の ブリージングモード (radial breathing modes ; RBMs)に 対応するピークが観測されている.22),25),26) そのピーク位 置はチューブの直径の逆数に比例することが知られてい る.27) それによると，図8aに見られるピーク，388，326， 278，261，225，206，161，154 $\mathrm{cm}^{-1}$ はそれぞれ直径 0.58 , $0.69,0.80,0.86,0.99,1.09,1.39,1.45 \mathrm{~nm}$ の穴に対応す る。試料によっては,ささらに細い穴に対応するラマンス ペクトルのRBMs ピークも得られている. 例えば, 437 あるいは $499 \mathrm{~cm}^{-1}$ に直径 0.51 および $0.45 \mathrm{~nm}$ の穴に対応 するピークも得られている。.26) また, 最小の穴 4 A に対応 するRBMs ピークも570 $\mathrm{cm}^{-1}$ の位置に稀に見られる。こ のように, RBMs が観測されるということは, 水素ガスア ーク放電で作製したMWNTs が，1 次元の量子細線として も有用であることを示唆する。

一方, 図8bの高波数領域では, グラファイトと類似の 強い $\mathrm{E}_{2 \mathrm{~g}}$ モードのピークが $1,583 \mathrm{~cm}^{-1}$ に観測される。た だし,グラファイトの場合に比し半值幅が約 2 倍と大き 

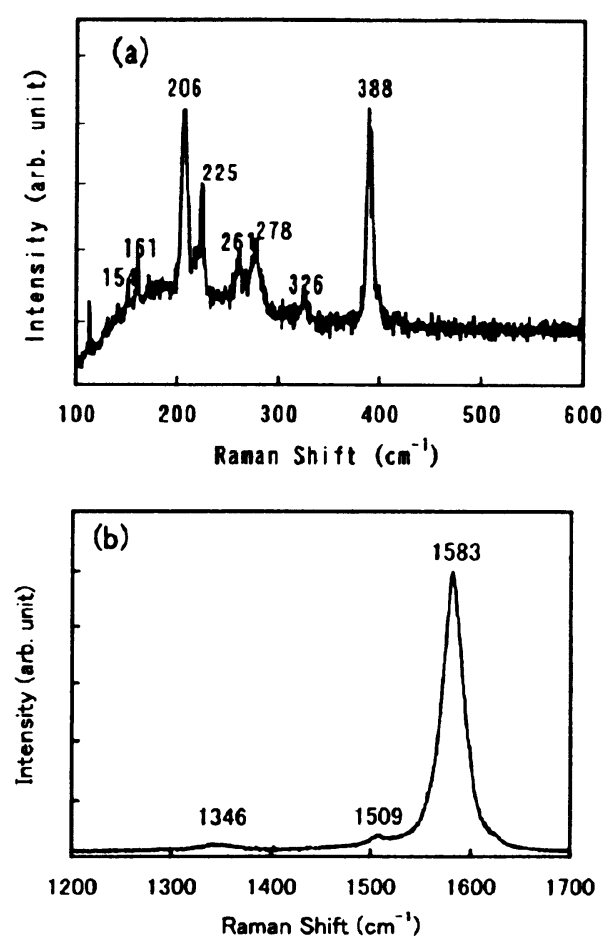

図 8 MWNTs のラマンスペクトル. (Raman spectra of MWNTs.)（a）低波数領域,（b) 高波数領域.

いのは,この MWNTs に特徴的な結果であり, そのピー

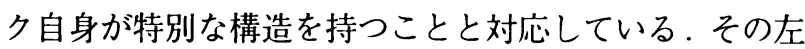
肩の弱いピーク $\left(1,509 \mathrm{~cm}^{-1}\right)$ はSWNTs の場合にも見ら れるが，通常の不活性ガス中で作製した中心の穴の太い MWNTsでは見られていない. また，非晶質カーボンに対 応すると言われる $1,346 \mathrm{~cm}^{-1}$ のピーク強度が大変弱いこ とは，作製された MWNTs の結晶性が極めて高いことの 裏付けでもある.さらに，この図の範囲では見られない が, $1,850 \mathrm{~cm}^{-1}$ 近傍に従来の理論では予測されない新しい ピークが見出されている。 それは, ラマンスペクトルを 得るための入射光のパワーが $20 \mathrm{~mW}$ と弱い方が強く, 入射光の分極にも依存した強度变化をすることが見出さ れた.28）また，作製条件としては，雲囲気ガスの水素圧 力が低い方がこのピークのラマン強度は強くなる.21) し かし，そのピークの由来はいまだ特定できてはいない。

\subsection{MWNTs の電気的特性}

図5のように精製したMWNTsのスポンジ状集合体の 中から 1 本の MWNT をマイクロマニピュレータで取り出 して, その電気伝導度を測定することができる.29) その測 定を九州工大の金藤に行ってもらった結果, 直径 $35 \mathrm{~nm}$ の MWNT に電流 $100 \mu \mathrm{A}$ を流すことができることが確認 された。それは, 電流密度にすると, $10^{7} \mathrm{~A} / \mathrm{cm}^{2}$ という大 きな值であることがわかる．また，個々のMWNTに対す る電気抵抗の温度変化を測定したところ, 図 9 に示すよ うな結果が得られた。21) すなわち, 温度を液体窒素温度あ るいはそれ以下まで減少させたところ, 抵抗值が増大す

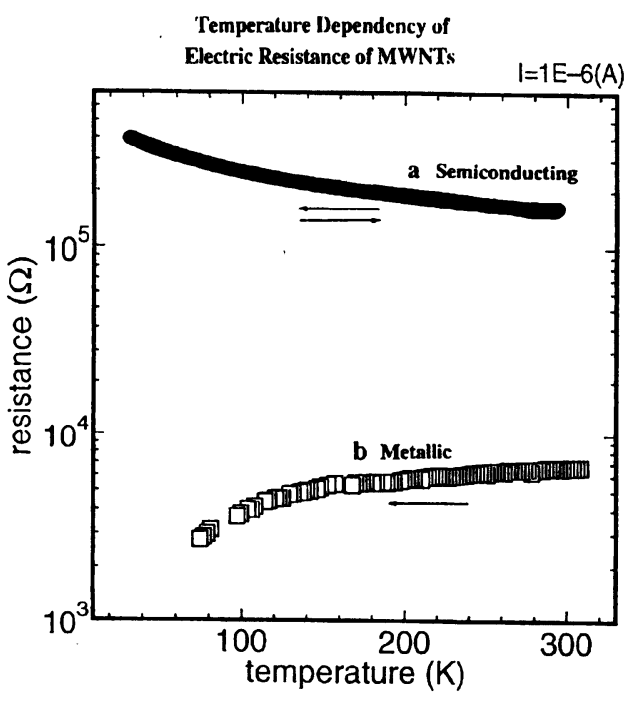

図 9 MWNTs $の$ 電気抵抗の温度变化. (Temperature dependence of electric resistance of MWNTs.)

る場合と減少する場合の両方があることが確認された． 前者は半導体的であり，後者は金属的である. SWNTsに その両方の種類のものがあることはそのカイラリティー (螺旋度) と直径に対応して理論的に予測されている. MWNTs にもその両方の種類のものが実際に存在するこ とが実験的に確認されたわけである.

さらに，図5のスポンジ状の MWNTs そのままを用い て, 片面に電極をつけて電界放出の測定をすることも可 能である. ${ }^{30)}$ 伊勢電子の上村によってその測定を行って もらった結果, 水素ガス中アーク放電で作製した MWNTs は, 高輝度の電子源として使用でき, 実用化の期待も高 いことが明らかになった.21) また, 図6のようなマット状 の MWNTs の生成物の場合も, 数 $\mathrm{mm}^{2}$ の広い範囲にわた って高輝度の電子放出が観測された。

\section{4. アーク放電による SWNTs の作製}

アーク法に限らず, SWNTs を作製する場合には, 蒸発 電極として適当な金属触媒の入った黒鉛電極を用いるこ とは不可欠の条件である。もう1つ,アーク放電で MWNTs の場合と本質的に異なるのは, MWNTs は陰極堆 積物という限られた場所にだけ存在するのに対し， SWNTs は蒸発容器の中全体に, くもの巣状に存在する ことである. 逆に, SWNTs は陰極堆積物の中には存在し ないということは, 特筆すべきである。

\section{1 アークプラズマジェット法によるSWNTs の作製}

アーク放電でSWNTs を作製するとき, MWNTs とは 異なって陰極堆積物が少なくなるように工夫する必要が ある.図1に示した蒸発装置の電極の極性を反転させて, 上側の電極を陽極とするだけでも, 対流の関係で下側の 陰極に堆積する割合は低くなる.さらに, 積極的に 2 本の 電極を約 $30^{\circ}$ という鋭角に対置させることによって, 蒸 
発で生じたアークプラズマ流を電極の隙間から噴出させ る形にして,㓌極上への堆積を減らすことに成功した。こ の方法を我々はアークプラズマジェット法 (APJ 法) と命 名した、31) 図 10a拈よびbに，アーク放電で $4.2 \% \mathrm{Ni}-$ $1.0 \% \mathrm{Y}$ を含む黒鉛電極を蒸発させて得られたSWNTs を 含む煤の収量を描いたグラフを示す，図 10aはAPJ 法の 結果であり，図 10b は通常の電極を鉛直に対置（下側を 㓌極）させた結果である。図中の一点鎖線は陽極の蒸発 速度を表し, 実線は煤として得られる部分の生成速度, 点 線は陰極に堆積する速度を表す．SWNTs を含む煤の生 成速度が高いAPJ 法が通常のアーク法よりはるかに望ま しいことがわかる、いずれの場合も，アーク電流の増大 とともに生成速度も増大している。

APJ 法で $4.2 \% \mathrm{Ni}-1.0 \%$ Y を含む黒鉛電極を蒸発させ て, 得られた煤の高分解能 SEM 像の一例を図 11 に示す. そこに見られるファイバー状のものは, SWNTsのバン ドルであることは高分解能TEM 像で確認されている. 粒 子状のもので白い強いコントラストを示しているのは, $\mathrm{Ni}$ の微粒子であることがTEM およびエネルギー分散型 (EDX) の元素分析装置を設置したSEM で確認されてい る。コントラストの高くない粒子は, 炭素のナノ粒子で ある。作製された場所によって, SWNTsのバンドルとナ ノ粒子の共存の割合は異なっている。 その両方を含む煤 の生成速度はかなり大きく, 数分間の APJ 蒸発で $1-2 \mathrm{~g}$ を 得ることは容易である。したがって，それを用いた応用 が期待される。

\section{2 水素ガス中アーク放電による SWNTs の作製}

前々節で，アーク蒸発によるMWNTs の作製に水素ガ スが有効であることを述べたが，SWNTs の場合にも同 じことが言えるかどうかを調べてみた，その結果，純粋 な水素ガス中で蒸発を行った場合, SWNTsが作製でき るのは，陽極に単元素の触媒金属 Feを $0.6 \%$ あいは $1.2 \%$ 混入させた黒鉛電極を用いた場合に限られていた。 その他の単元素 Ni あるいはCo を混入させた電極，ある いはそ机らを混ぜた 2 元金属あるいは 3 元金属を含む黒
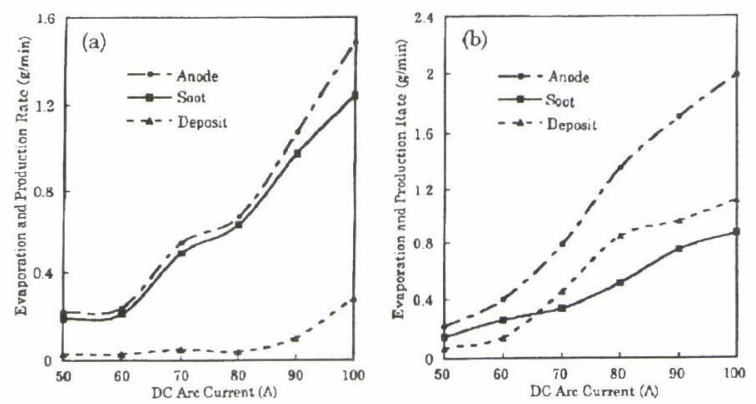

図10 SWNTs 含含煤の収量の比較. (Comparison of yield of soot including SWNTs.) (a) アークプラ ズマジェット法, (b) 通常のアーク法.
鉛電極を水素ガス中で蒸発させたのでは, SWNTs は作 製できないことがわかった。

ところが, 水素ガス 500 Torrに $1 \%$ の $\mathrm{H}_{2} \mathrm{~S}$ ガスを添加 すると, 金属の触媒効果が著しく活性になり, SWNTsが 作製できることがわかった。このように，イオウが添加 されると触媒効果が促進されることは知られていたが,32) それが $\mathrm{H}_{2} \mathrm{~S}$ ガスという状態でも効果があることが確認さ れたわけである、33) $1 \%$ の $\mathrm{H}_{2} \mathrm{~S}$ ガスを添加した場合は, 鉄 族の遷移金属 $\mathrm{Fe}, \mathrm{Co}, \mathrm{Ni}$ のいずれもが有効で SWNTs を作 製することができ，さらにそれらを二種類ずつ混合した 場合もSWNTs を作製でき，3種類の触媒金属を混入した 場合には最もよくSWNTsが作製できることがわかった。 さらに，それらのSWNTs を高分解能TEM で観察すると， 図12に示すようにSWNTs の内側にもう一枚のレイヤー が生成された2層カーボンナノチューブ (DWNTs) がで きている場合もあることがわかった。この場合には， SWNTsの中にアモルファスの炭素がかなり多く取り込ま れて抢り，それが高温雲囲気の中に保持されることによ り，第2の層に成長したものと思われる。

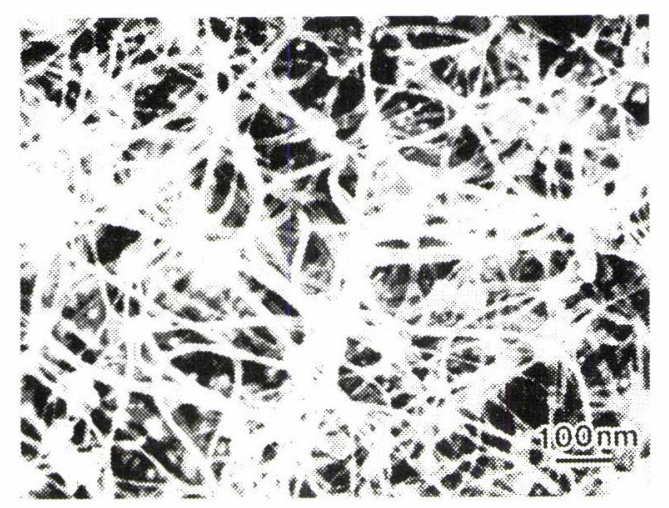

図11 アークプラズマジェット法で作製したSWNTsの SEM 像. (SEM micrograph of SWNTs produced by arc plasma jet method.) 


\section{5. おわりに}

アーク放電による黒鉛棒の蒸発で, 多層と単層のカー ボンナノチューブ (MWNTs とSWNTs) を作製する方法 について述べてきた。高品質の MWNTsを作製するには， 純粋な水素ガス雲囲気が適当であり，その精製も赤外線 照射加熱で容易に行える。 それは, 中心の穴が極めて細 く，それに対応するラマン散乱のブリージングモードも 観測できている.さらに, この MWNTsは特徴的な物性 を示し，1次元の量子細線とみなすことができる.また， 電気伝導度が高く, 電界放出の輝度も高いことからその 応用が望まれるところである.SWNTsについても、アー クプラズマジェット法である程度, 量産化できることが 可能になったので, その特性を活かした応用研究も進め ることができる。

\section{謝 辞}

本報告は日本学術振興会外国人特別研究員の趙 新洛 博士の協力によるところ, 極めて大である. 高分解能 TEM 観察においては, 本学材料機能工学科の飯島澄男教 授, 科学技術振興事業団の平原佳織さん, 秦禄昌博士の 協力を得た. ラマン測定に関しては, 本学電気電子工学 科平松美根男助教授の協力を, 電気伝導度測定では九州 工業大学の金藤敬一教授の協力を, 電子放出の測定では 伊勢電子工業の上村佐四郎氏の協力を得た。ここに, 皆 さんに感謝の意を表する。また, 本研究の一部は, 文部 科学省の科学研究費補助金「特定領域研究」,「基盤研究 (A) 」, 「基盤研究 (B)」,「基盤研究 (C)」などいくつかの援 助によって行われた，合わせて感謝の意を表する。

\section{文 献}

1) S. Iijima: Nature 354, 56 (1991).

2) S. Iijima: J. Cryst. Growth 50, 675 (1980).

3) H. W. Kroto, J. R. Heath, S. C. O'Brien, R. F. Curl and R. E. Smalley: Nature 318, 162 (1985).

4) S. Iijima: J. Phys. Chem. 91, 3466 (1987).

5) S. Iijima and T. Ichihashi: Nature 363, 603 (1993).

6) D. S. Bethune, C. H. Kiang, M. S. de Vries, G. Gorman, R. Savoy, J. Vazquez and R. Beyers: Nature 363, 605 (1993).

7) M. José-Yacamán, M. Miki-Yoshida, L. Rendón and J. G. Santiesteban: Appl. Phys. Lett. 62, 202 (1993).

8) M. Kusunoki, M. Rokkaku and T. Suzuki: Appl. Phys. Lett. 71, 2620 (1997).

9) M. Kusunoki, T, Suzuki, K. Kaneko and M. Ito: Phil. Mag. Lett. 79, 153 (1999).

10) A. Thess, R. Lee, P. Nikolaev, H. Dai, P. Petit, J. Robert, C. Xu, Y. H. Lee, S. G. Kim, A. G. Rinzler, D. T. Colbert, G. E. Scuseria, D. Tománek, J. E. Fischer and R. E. Smalley: Science 273, 483 (1996).
11) 安藤義則：日本結晶学会誌 36, 259 (1994).

12) R. Uyeda: J. Cryst. Growth 45, 485 (1978).

13) Y. Ando and M. Ohkohchi: J. Cryst. Growth 60, 147 (1982).

14) W. Krätschmer, L. D. Lamb, K. Fostiropoulos and D. R. Huffman: Nature 347, 197 (1990).

15) Y. Ando: Jpn. J. Appl. Phys. 32, L1342 (1993).

16) X. Zhao, M. Wang, M. Ohkohchi and Y. Ando: Jpn. J. Appl. Phys. 35, 4451 (1996).

17) M. Wang, X. Zhao, M. Ohkohchi and Y. Ando: Fullerene Science \& Technology 4, 1027 (1996).

18) X. Zhao, M. Ohkohchi, M. Wang, S. Iijima, T. Ichihashi and $Y$. Ando: Carbon 35, 775 (1997).

19) Y. Ando, X. Zhao and M. Ohkohchi: Carbon 35, 153 (1997).

20) Y. Ando, X. Zhao and M. Ohkohchi: Jpn. J. Appl. Phys. 37, L61 (1998).

21) Y. Ando, X. Zhao, H. Kataura, Y. Achiba, K. Kaneto, M. Tsuruta, S. Uemura and S. Iijima: Diamond Related Mater. 9, 847 (2000).

22) 安藤義則, 趙 新洛: 材料 50, 357 (2001).

23) H. Kataura, Y. Achiba, X. Zhao and Y. Ando: Mat. Res. Soc. Symp. Proc. 593, 113 (2000).

24) L. C. Qin, X. Zhao, K. Hirahara, Y. Miyamoto, Y. Ando and S. Iijima: Nature 408, 50 (2000).

25) X. Zhao and Y. Ando: Jpn. J. Appl. Phys. 37, 4846 (1998).

26) Y. Ando, X. Zhao and H. Shimoyama: Carbon 39, 569 (2001).

27) R. Saito, T. Takeya, T. Kimura, G. Dresselhaus and M. S. Dresselhaus: Phys. Rev. B 57, 4145 (1998).

28) Y. Ando, X. Zhao, H. Kataura, Y. Achiba, K. Kaneto, S. Uemura and S. Iijima: Trans. Mater. Res. Soc. Japan 25, 817 (2000).

29) K. Kaneto, M. Tsuruta, G. Sakai, X. Zhao and Y. Ando: Synthetic Metals 103, 2543 (1999).

30) Y. Saito, S. Uemura and K. Hamaguchi: Jpn. J. Appl. Phys. 37, L346 (1998).

31) Y. Ando, X. Zhao, K. Hirahara, K. Suenaga, S. Bandow and S. Iijima: Chem. Phys. Letters 323, 580 (2000).

32) C. H. Kiang, W. A. Goddard III, R. Beyers, J. R. Salem and D. S. Bethune: J. Phys. Chem. 98, 6612 (1994).

33) Y. Ando, X. Zhao, K. Hirahara and S. Iijima: "Proc. Internat. Symp. Nanonetwork Materials: Fullerenes, Nanotubes, and Relat. Materials (ISNM2001)", in printing (2001).

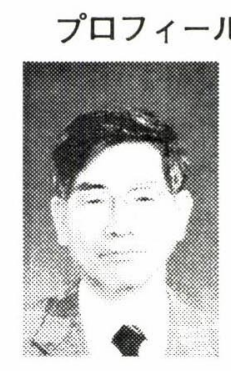

\section{安藤義則 Yoshinori ANDO}

名城大学理工学部材料機能工学科

Department of Materials Science and Engineering, Meijo University

干 468-8502 名古屋市天白区塩釜口 1-501

1-501 Shiogamaguchi, Tenpaku-ku, Nagoya 4688502, Japan

TEL. 052-832-1151 (5280), FAX. 052-832-1170 e-mail: yando@ccmfs.meijo-u.ac.jp 最終学歴：名古屋大学大学院工学研究科博士課程 専門分野: 結晶物理学, 無機材料

現在の研究テーマ:カーボンナノチューブの作製 趣味：テニス, 囲碁 